\title{
TOWARDS A MODEL OF REDUCING STATELESSNESS: AN ANALYSIS OF THE EFFICACY OF CHILE'S STATELESSNESS REDUCTION PLAN, \#CHILERECONOCE
}

\author{
HACIA UN MODELO PARA REDUCIR LA APATRIDIA: \\ ANÁLISIS DE LA EFICACIA DEL PLAN DE REDUCCIÓN \\ DE LA APATRIDIA DE CHILE, \#CHILERECONOCE
}

Richard T. Middleton IV $V^{a^{*}}$ and Teresa Flores ${ }^{b}$

Fechas de recepción y aceptación: 21 de julio de 2020 y 14 de octubre de 2020

DOI: $10.46583 /$ scio_2020.19.719

Abstract: This paper examines the efficacy of a statelessness reduction plan implemented by the country of Chile. We evaluate the programmatic alignment of Chile's statelessness reduction plan, \#Chilereconoce, with policy enacted by the United Nations High Commissioner for Refugees in that office's campaign to eradicate statelessness by the year 2024. In addition to evaluating the structure of Chile's statelessness reduction plan, we explore the policy outcomes of this plan in achieving its desired goal of reducing statelessness in Chile. We use Chile as a case study because it implemented the United Nations High Commissioner for Refugees' 2014-2024 Action Plan and, therefore, can shed light on if such a plan can put a nation-state on the path to remedy the deleterious effects of statelessness. Our central argument is that Chile's statelessness reduction plan can, in-fact, serve as a blueprint for governmental institutions to follow towards achieving the goal of reducing statelessness. The success of such a plan, however, is

${ }^{a}$ Faculty of Political Science. School. Law School. University of Missouri-St. Louis

${ }^{*}$ Correspondencia: University of Missouri-St. Louis. Faculty of Political Science. One University Boulevard 347 SSB. St. Louis. Missouri 63121. Estados Unidos de América.

E-mail: middletonrt@umsl.edu

${ }^{\mathrm{b}}$ Florence Immigrant and Refugee Rights Project (Florence Project). 
conditioned upon whether principle actors within governmental institutions confront, head on, structural challenges that otherwise tend to undermine the merging of a confluence of critical factors that must be aligned for success to occur. The Chilean project demonstrates that reducing statelessness requires community action, implementation of domestic legislative reform, and governmental accession to international treaties.

Keywords: Statelessness, human rights, \#Chilereconoce, Chile, Global Action Plan.

Resumen: Este artículo examina la eficacia del plan de reducción de la apatridia implementado en Chile. Evaluamos el alineamiento programático del plan \#Chilereconoce con las políticas promulgadas por la oficina del Alto Comisionado de las Naciones Unidas para los Refugiados en su campaña para erradicar la apatridia en el año 2024. Además de evaluar la estructura del plan de Chile para la reducción de la apatridia, exploramos los resultados de las políticas de este plan para alcanzar el objetivo deseado, esto es, la reducción de la apatridia en Chile. Elegimos el caso de Chile porque su gobierno ha implementado el Plan de Acción 2014-2024 del Alto Comisionado de las Naciones Unidas para los Refugiados y, por lo tanto, puede arrojar luz sobre si este plan puede poner a una Estado nación en vías de remediar los efectos nocivos de la apatridia. Nuestro argumento central es que el plan de reducción de la apatridia de Chile puede, de hecho, servir como hoja de ruta a seguir por instituciones gubernamentales para conseguir reducir la apatridia. El éxito de este plan, sin embargo, depende de que actores principales dentro de las instituciones gubernamentales se enfrenten directamente a desafíos estructurales que, de otra manera, tienden a socavar la confluencia de una serie de factores críticos que deben alinearse para que se produzca el éxito. El proyecto chileno demuestra que reducir la apatridia requiere acción por parte de la comunidad, implementación de reformas legislativas domésticas y la adhesión de los gobiernos a tratados internacionales.

Palabras clave: Apatridia, derechos humanos, \#Chilereconoce, Chile, Plan de Acción Global. 


\section{§1. INTRODUCTION}

This paper examines the efficacy of a statelessness reduction plan implemented by the country of Chile. More specifically, we evaluate the programmatic alignment of Chile's statelessness reduction plan with policy enacted by the United Nations High Commissioner for Refugees (UNHCR) in that office's campaign to eradicate statelessness by 2024. The UNHCR's Global Action Plan to End Statelessness: 2014-2024 (2014-2024 Action Plan) sets forth a guiding blueprint of ten actions to be undertaken by nation-states to: (1) resolve existing major situations of statelessness, (2) prevent new cases of Statelessness from emerging, and (3) better identify and protect Stateless populations ("Global Action Plan to End Statelessness," 2014). In addition to evaluating the structure of Chile's statelessness reduction plan, we explore the policy outcomes of this plan in achieving its desired goal towards reducing statelessness in Chile. We use Chile as a case study to analyze whether the implementation of the UNHCR's 2014-2024 Action Plan can put a nationstate (hereinafter also referred to as "State") on the path to remedy the deleterious effects of legal rules and political decisions that place migrant, minority and/or indigent populations at risk of statelessness. Our central argument is that Chile's statelessness reduction plan can in-fact serve as a blueprint for governmental institutions to follow towards the goal of reducing statelessness. Our analysis demonstrates that the success of such a plan, however, is conditioned upon whether principle actors within governmental institutions confront, head on, structural challenges - including legal deficiencies, bureaucratic discretion, policy shortcomings, and a lack of access to justice - that otherwise tend to undermine the merging of a confluence of critical factors that must be aligned for success to occur. We conclude our analysis by finding that the Chilean model demonstrates that reducing stateless requires community action, implementation of domestic legislative reform that espouses core tenets of human rights, and governmental accession to international treaties aimed at ending statelessness.

Historically, the condition of statelessness in Chile often began with the government's failure to legally acknowledge (i. e., register) certain births in the country based on Chile's legislative interpretation of the country's 
constitutional language regarding persons born to an individual deemed to be "in-transit" in the country. The administrative practices that evolved as a result of the legal interpretation of "in-transit" had the corresponding effect of denying children born in such instances access to health care and education on coterminous terms to children holding full Chilean enfranchisement. Chile undertook an effort to address this reality by revisiting its laws relative to access to birth registration. For example in 2014, "the Department of Foreign and Migration Affairs issued an administrative order stating the 'in transit' exception would only encompass the children of tourists and crew members serving on a vessel. Under this new interpretation, undocumented migrants [were] not considered to be in transit, and accordingly their children born in Chile are considered Chilean" ("Born in the Americas: The Promise and Practice of Nationality Laws in Brazil, Chile, and Colombia" 2017: 49). In addition, Chile provided a method of seeking legal recourse to assert such citizenship rights by enacting legislation that allowed individuals to bring a claim in court in order to request the tribunal grant the petitioner Chilean nationality. One notable limitation with these measures, however, was that most of the affected populations - migrants and indigenous groups (who resided in northern Chile)- did not have meaningful access to the resources needed (e.g., transportation, language access, finances) to bring their claims in court. Beyond this limitation, however, Chile has since acceded to binding international conventions to prevent statelessness and protect those who have been rendered stateless. Chile has also enjoined the UNHCR and cooperated in its effort to eradicate statelessness by the year 2024 by joining Brazil's Declaration and Plan of Action and by launching its own initiative known as \#Chilereconoce (\#ChileRecognizes) ("Brazil Declaration and Plan of Action," 2014).

Chile began to implement its \#Chilereconoce campaign sometime in the latter part of the year 2016. As a result, there is a limited number of scholarly works on this particular stateleness reduction campaign. There exists one such work, however, by Delfina Lawson and Macarena Rodriguez (2017) that explores this movement in great detail. In their work, Lawson and Rodriguez evaluate the transformation of addressing statelessness from strategic litigation to the creation of the \#Chilereconoce campaign (Lawson and Rodriguez, 2017). Among the findings of their study, they identified Chile had "denied nationality to at least 4,000 children born in the country based solely on their 
parents' irregular migratory status" (Lawson and Rodriguez, 2017: Abstract). They further identified there were still children who still had defective birth certificates that registered them as "Child of Transient Foreigner" instead of providing them with Chilean nationality (Lawson and Rodriguez, 2017: 1). In 2016, through a collaborative effort of immigrant rights advocates who litigated before the Supreme Court of Justice in Chile, 100 children "were recognized as Chilean nationals, and administrative changes were brought about so as to ensure the right to a nationality to all people born in the country" (Lawson and Rodriguez, 2017: 8). While this number may not seem like a robust figure, it is nevertheless an indication that Chile was moving in a positive direction with regards to reducing statelessness. However, reports from the field indicated that much work was left to be done.

In 2017, the Open Society Justice Initiative produced a report, "Born in the Americas: The Promise and Practice of Nationality Laws in Brazil, Chile, and Colombia" in an effort to assess each of these country's citizenship laws and practices and the extent to which they extended legal rights to minority populations. This report was the first of its kind to be completed after the inauguration of the \#Chilereconoce initiative. In a nutshell, the report concluded that relative to the constitutional construct of birthright citizenship in Chile:

there is reason for concern that anti-immigration sentiment within specific interest groups may drive the adoption of harsher domestic legislation, particularly the 'in transit' exception, restricting the right to nationality of children born in Chile to foreign nationals. Furthermore, under the previous interpretation of the transient foreigner exception, many children were unable to access Chilean nationality. These children must file a petition before the Department of Foreign and Migration Affairs or through a judicial recourse before the Supreme Court in order to gain Chilean nationality (2017: 50)

This report demonstrated that even despite the legal remedies fashioned in the 2016 case before the Supreme Court of Justice in Chile, anti-immigrant sentiment held by bureaucrats imbued with decision-making power had the potential to lead to disparate, inconsistent, and discriminatory results in the extension of citizenship status to affected populations. Consequently, changes in law alone were not enough to catalyze enduring change. 
In this paper, we first provide a brief overview of the issue of statelessness and its associated deleterious effects. In doing so, we draw into the discussion some of the major international human rights doctrines that set forth guiding principles and practices relative to self-identity, nationality, membership into a national community, and methods to prevent the creation of statelessness. We then provide a brief history of the office of the United Nations High Commissioner for Refugees (UNHCR) and what galvanized this office to take on the project of creating a guiding framework (2010-2014 Action Plan) towards eradicating statelessness. We also provide an overview of the relevant governing international conventions that undergird the 2014-2024 Action Plan. In doing so, we examine the campaign referred to as \#IBelong - which was launched on November 4, 2014, and served as the springboard for the UNCHR 2014-2020 Action Plan. Finally, we delve into Chile's course of action towards implementing the framework of the 2014-2020 Action Plan to provide some insights into whether Chile's approach can serve as a model for an effective and sustainable plan to reduce statelessness.

\section{§2. What IS STATELESSNess?}

The term statelessness is used to refer to individuals who are left rendered without a nationality ("Self-Study Module on Statelessness," 2012). According to a study conducted by the UNHCR, more than $75 \%$ of the world's known stateless population belong to minority groups ("This Is Our Home," Stateless Minorities and Their Search for Citizenship, 2017: 1) (In defining "minority," this same report notes, "while there is no internationally agreed definition of a minority, it is commonly accepted that a minority is an ethnic, religious or linguistic group, fewer in number than the rest of the population, whose members share a common identity (6))." In addition, statelessness is often a generational problem - thus it has the potential to permeate its deleterious effects across generations if it is not addressed ("“This Is Our Home"”: 1). Statelessness can arise as the result of numerous factors - among them including discrimination in nationality laws, conflicts between and gaps in nationality laws and State succession laws, as well as legal interpretations of 
constitutional, statutory, and policy concepts that create the confines of the acquisition of nationality (Arnold, n. d.). Statelessness can also arise when individuals are displaced and bear children outside their country of nationality and that country does not either recognize jus soli or, if having jus soli, does not espouse a broad, un-abrogated application of jus solis (birthright by soil) (Arnold, n.d.). Statelessness can occur de facto when an individual lacks a birth certificate evidencing nationality or does not have access to obtain any certification recognizing them as a person with nationality or citizenship of a particular place.

Although there are treaties and conventions in place that fashion safeguards against statelessness, States must accede to such treaties and conventions and agree to enforce them ("Global Action Plan to End Statelessness," 2014: 6). Furthermore, international laws sometime create paradoxical situations in that these edicts often hold that States have the sovereign right to determine, change or refute nationality among individuals residing in their States ("Global Action Plan to End Statelessness," 2014: 6). One of the main reasons why statelessness still exists and remains a problem is that States often resist being bound by international treaties regarding statelessness. There are various conventions that dictate that under international law, nationality is a non-derogable right - meaning that it cannot be usurped by a State's own laws. Some of the more prominent conventions and treaties that declare such a right include the following: the Universal Declaration of Human Rights (UDHR); the International Covenant on Civil and Political Rights (ICCPR); the Convention on the Elimination of All Forms of Discrimination Against Women (CEDAW); and the Convention on the Rights of the Child (CRC) ("Global Action Plan to End Statelessness," 2014: 6).

International laws are sometimes said to be customary and create moral obligations to follow them. In some instances, international laws are binding on States that ratify them. In either case, there often arises the need for an arbiter to hear disputes between parties when an allegation of a violation of a human right is made. The International Court of Justice (ICJ) was created by the United Nations as the judicial organ of the United Nations to settle disputes between states arising under international law (Statute of the International Court of Justice, 1946). The Statute of the International Court of 
Justice, which comes directly from the ICJ, provides under Article 38, Section 1, that international conventions are the highest form of persuasive and binding law. Chile ratified the Vienna Convention on the Law of Treaties on April 9, 1981, and as such agreed to be bound by its laws. Under Article 26 of the Vienna Convention on the Law of Treaties, "every treaty in force is binding upon the parties to it and must be performed by them in good faith" (Vienna Convention on the Law of Treaties, 1969). Therefore, Chile is bound to uphold the laws of any treaty to which it accedes. One significant limitation to an individual's ability to seek relief before the ICJ, however, is that "the only contentious cases the ICJ can hear are cases between States. This is an important difference between the ICJ and other human rights institutions that allow some type of direct access. Individuals have no right of direct access... It does not mean that energetic and imaginative counsel can never get individual clients' situations before the Court... Still, it is a significant limitation" (Crook, 2004: 2).

The Universal Declaration of Human Rights (UDHR), while not a treaty in itself, has been recognized as arising to customary international law. Such a body of law arises when States behave in a manner consistent with how they believe the law mandates they must act. According to scholarship in this field, the elements of customary international law include: (1) the widespread repetition by States of similar international acts over time (State practice); (2) the requirement that the acts must occur out of a sense of obligation (opinio juris); and (3) that the acts are taken by a significant number of States and not rejected by a significant number of States ("International Legal Research Tutorial," citing Rosenne, 1984). Article 15 of the Universal Declaration of Human Rights speaks to statelessness; it mandates that everyone has the right to nationality, and no one shall be arbitrarily deprived of his/her nationality (Universal Declaration of Human Rights, 1948: Article 15). This is a critical human right to hold because individuals who are denied nationality frequently encounter obstacles when it comes to access to health services, education, the ability to obtain identification documents and other fundamental rights (Lawson and Rodriguez, 2017: 1). Lamentably, enforcement of international law such as the UDHR is made difficult, if not impossible, in instances where violations occur in non-acceding States. 
Another important human rights document is the Convention Relating to the Status of Stateless Persons. The purpose of this 1954 Convention is to ensure that all stateless individuals enjoy a minimum set of rights, beginning at birth, until they can acquire nationality. This convention served to first identify stateless individuals as all of those who are not considered a national by any State. The convention offered all individuals juridical status, along with rights relating to employment and welfare. Article 3 of the Convention states that the rights provided in the convention extend to all stateless individuals regardless of race, religion, or country of origin. The Convention seemingly works to reiterate that a sense of reciprocity should exist between the stateless people and the States in which they are residing in. Just as stateless individuals must obey the laws of the State that they are residing in, they should also be afforded the same protections in return.

The 1961 Convention on the Reduction of Statelessness aims to implement legal safeguards to prevent individuals from becoming stateless and to reduce the prevalence of statelessness over time. This convention serves to reiterate and reinforce the main concepts implemented in the Convention Relating to the Status of Stateless Persons, but it also asserts that nationality shall be granted as an operation of law granted to anyone who is born in a State's territory and would otherwise be rendered stateless. This Convention further serves to establish rules that limit the occurrence of statelessness and also to further promote Article 15 of the United Nations Declaration of Human Rights. Additionally, it serves to tackle statelessness at the outset by providing that prevention of Statelessness could more easily be realized if all children were granted citizenship and nationality at birth. Article 1 of the Convention on the Reduction of Statelessness specifically States that, "a Contracting State shall grant its nationality to a person born in its territory who would otherwise be Stateless. Such nationality shall be granted: (a) at birth, by operation of law, or (b) upon an application being lodged with the appropriate authority (Convention on the Reduction of Statelessness, 1961). While the Convention outlines safeguards to protect against Statelessness, the key term is "Contracting States," which requires States to be parties to the convention and accede to its laws. This serves to be problematic given that not all member States of the United Nations have acceded to either Conventions. 
Although the 1954 Convention Relating to the Status of Stateless Persons and the 1961 Convention on the Reduction of Stateless serve to directly address statelessness, there is another convention that, if implemented and applied at the birth of an individual, serves the purpose of preventing statelessness from its most incipient stages. This convention is the 1990 Convention on the Rights of the Child (CRC). The purpose of the CRC is to outline a set of rules that are meant to ensure that every child grows up in an atmosphere of happiness, love and understanding (Convention on the Rights of the Child, 1990). These rights are extended to every child regardless of race, color, sex, language, religion, political or other opinion, national or social origin, property, birth or other status. Under Article 7, Section 1, of the Convention on the Rights of the Child, "a child shall be registered immediately after birth and shall have the right from birth to a name, the right to acquire a nationality and as far as possible, the right to know and be cared for by his/ her parents."

\section{§3. ThE UNHCR AND ITS ROLE IN ERADICATING STATELESSNESS}

Since its creation in the 1950s, the United Nations High Commissioner for Refugees has not always taken on a leading role in the advocacy of reducing and eradicating statelessness. Sometime around 2008, various influential international non-governmental organizations (NGOs) and other monitoring bodies began to actively campaign to bring awareness to issues of statelessness and the populations affected by it (Blitz and Lynch, 2012: 3). The effort on how to target and address statelessness was embarked upon by the United Nations High Commissioner for Refugees with the help of the Committee on the Elimination of Racial Discrimination, the Office of the High Commissioner for Human Rights (OHCHR), and other UN agencies (Blitz and Lynch, 2012: 3). In October 2013, the UNHCR began to take steps towards coming up with a resolution towards formulating a policy agenda for eradicating stateless; one major idea developed was calling for the commitment of the entire international community to band together to end statelessness ("Global Action Plan to End Statelessness," 2014: 4). 
In November of 2014, the UNHCR announced the launch of their new campaign, the \#IBelong Campaign, which aimed to eradicate statelessness by 2024 via addressing and remedying existing worldwide statelessness ("Global Action Plan to End Statelessness," 2014: 4). The purpose of the campaign was to encourage States to join the Global Action Plan, which outlined that in order to address statelessness there were three main goals that needed to be achieved. The first was that States needed to resolve current issues of statelessness that existed in their jurisdictions. Towards achieving this goal, the UNHCR challenged States to hold themselves accountable for recognizing that they had a problem that needed to be resolved. The second goal was to prevent new cases of statelessness from emerging. The third, and last goal, was to better identify and protect stateless persons in each State. The UNHCR sought to provide on-the-ground assistance; but, the office mainly called for States to take responsibility and account for problems that exist in their respective States that have created and fostered Statelessness.

In order to ensure the success of its three goals, the United Nations High Commissioner for Refugees created a 10-step action plan towards achieving the office's goal of eradicating statelessness ("Global Action Plan to End Statelessness," 2014: 4). The plan is as follows:

- Action 1: Resolve existing major situations of statelessness

- Action 2: Ensure that no child is born stateless

- Action 3: Remove gender discrimination from nationality laws

- Action 4: Prevent denial, loss or deprivation of nationality on discriminatory grounds

- Action 5: Prevent statelessness in cases of State succession

- Action 6: Grant protection status to stateless migrants and facilitate their naturalization

- Action 7: Ensure birth registration for the prevention of statelessness

- Action 8: Issue nationality documentation to those with entitlement to it

- Action 9: Accede to the UN statelessness conventions

- Action 10: Improve quantitative and qualitative data on stateless populations 
The UNHCR theorized that if all ten action plans were executed, then this could solve the issues of statelessness on a global level and it could be achieved within ten years.

\section{§4. Background of the ChILEAN historicAl APPROACH tO BiRTHRight CITIZENSHIP}

Chile, like many other States in Latin America, recognizes birthright nationality through the principle of jus soli and jus sanguinis. Globally, only a minority of States grant birthright citizenship via jus soli; and the majority of those that do espouse a mixed jus soli-jus sanguinis construct. The concept of jus soli has been a core principle of Chilean nationality as outlined in the Chilean Constitutions of 1828 and 1833 ("La Nacionalidad de los Hijos de Extranjeros," 2014: 4). Under the Chilean Constitutions of 1828 and 1833, Article 5 states that, "natural Chileans (are) all those born in the territory of the republic" ("La Nacionalidad de los Hijos de Extranjeros," 2014: 4). A revision to the Chilean Constitution of 1833 modified this wording, but essentially maintained the same legal construct (Constitucion Politica De La Republica De Chile, Art. 10.1). The Chilean Constitution has since gone through various iterations. Today, Chapter II, Article 10, Number 1, of the Chilean Constitution of 1980 (hereinafter, "Chilean Constitution") maintains that birthright citizenship in Chile is based on a hybrid mixture of jus sanguinis and jus soli. However, the current effective Chilean constitution creates exceptions to the jus soli doctrine of birthright citizenship that were not present in predecessor constitutions. Under Chapter II, Article 10, Number 1 of the Chilean Constitution:

Chileans are:

1. - Persons born in the territory of Chile, with the exception of those children of foreigners who are in Chile serving their government, as well of those children of transient foreigners.

However, all may opt for the Chilean nationality (Constitucion Politica De La Republica De Chile Art. 10.1). 
Ostensibly, the Chilean constitution's "in transit" clause does not unequivocally exclude children of transient foreigners born in Chile from Chilean citizenship. Article 10, Number 1 states that, "all may opt for the Chilean nationality." In order to opt for Chilean nationality an individual must submit a "Declaration to Opt to the Chilean Nationality" (Form M-2) and must submit this form within one year of turning twenty-one years of age ("Requisitos Para Optar a la Nacionalidad Chilena," Departamento de Extranjeria y Migracion, n. d.). The requirements listed in the M-2 form indicate that an applicant must submit a letter addressed to the head of the Alien Status and Immigration Department of the Ministry of Interior formally requesting to opt for the Chilean nationality. The applicant must also submit a birth certificate which would ascribe the applicant as "Child of an In-transit Foreigner." Finally, the applicant must submit a photocopy of an identification card if they have one. If an applicant is physically present in Chile, then they submit their application to the Correspondence Office of the Alien Status Department of the Ministry of Interior in Santiago, Chile, or to the Alien Status Office of the corresponding Provincial Government in their region. If an applicant is abroad, then they submit their application to the closest Chilean Consulate. On October 24, 2016, the age requirement by which a petitioner must opt for Chilean nationality was changed from twenty-one years of age to eighteen years of age ("Requisitos Para Optar a la Nacionalidad Chilena," Departamento de Extranjeria y Migracion, n.d.).

\section{§5. The "IN transit" CLause and Statelessness IN Chile}

The Chilean constitution's "in-transit" clause has had the effect of excluding children of the most vulnerable populations in Chile from obtaining Chilean citizenship. From 1995 to 2014, the Chilean interpretation of the term "in-transit" became problematic when it began to encompass all people who were in Chile on what was considered a "temporary basis". Under Article 20 of the Chilean Civil Code, the term was interpreted to mean "one who travels or goes through a place, that is on the way, who does not reside only transiently in one place" (Middleton and Wigginton, 2012: 537). Irregular 
migration is a term used to define the movement of persons to a new State for residence that occurs outside the regulatory norms of sending, transit and receiving countries ("Irregular Migration," n.d.). It is important to understand the ramifications and hardships that this status can cast on such populations through a more microlevel perspective. This can be achieved through an analysis of real-world examples. Broadly speaking, those individuals most affected by the interpretation of "in-transit" have been indigenous persons that have not been able to prove that they have maintained long-term permanent residency in Chile or who have not had access to birth registrations. Migrants are another population that has been significantly affected - especially those who have gone to Chile seeking work, tourism, or refugee/asylee status. The story of Noemi Marianela Meza Goni ("Noemi") is illustrative.

Noemi Marianela Meza Goni, of Peruvian citizenship, encountered the deleterious effects of the bureaucratic interpretation of the "in-transit" clause when it was applied to her residential status in Chile (Noemi was seven months pregnant when she entered Chile with a tourist visa on October 16, 2000. She entered the country along with her fiancé (Giancarlo Alexis Figueroa Meza, Sentencia No. 9422-2013, (2014)). In November of 2000, Noemi went into labor prematurely and gave birth to a son, Giancarlo Alexis Figueroa Meza ("Giancarlo"). Giancarlo was registered at birth as a "Child of Non-resident Foreigner." In June of 2002, Noemi and her fiancé married. Then, in October of 2002, Noemi adjusted her status from non-resident to resident and her husband did the same in April of 2004. In 2003 and 2010, Noemi and her husband bore other children, who under law were considered Chilean nationals. Giancarlo, on the other hand, was not initially deemed to be Chilean because his mother was said to have been in-transit when she gave birth to him. The effect of this was to divide the legal standing of the family - with all but Giancarlo enjoying the full gamut of rights and privileges commensurate with Chilean citizenship or lawful residency. In addition, Noemi's two children who were deemed to be Chilean citizens would realize benefits, rights, and protections that their older brother would not. When Giancarlo's parents attempted to amend Giancarlo's birth certificate, the Department of Civil Registry said it could not be changed because even though they were now residents, what mattered most was their status at the time of their child's birth. 
The untenable result in the case of Giancarlo would lead Noemi to go on to challenge this determination of his nationality and the ascription on his birth certificate of being a child of a non-resident foreigner. The Chilean Supreme Court, in a decision handed down on January 6, 2014, ruled that Giancarlo's parents "entered the national territory with the intention of remaining there, in such a way that it is not appropriate to classify them as transient foreigners"(Giancarlo Alexis Figueroa Meza, Sentencia No. 9422-2013, (2014)). Accordingly, Giancarlo should not be deemed the "child of non-resident foreigner." The Supreme Court of Chile ordered that this designation be removed from Giancarlo's birth certificate. This was a critical victory for the family. However, Giancarlo had spent a little over 13 years being stateless. He did not automatically acquire Peruvian citizenship at birth, via jus sanguinis, because Peruvian law did not grant him such status. Giancarlo could not have inherited Peruvian citizenship at his birth through his parents' holding Peruvian citizenship unless, in accordance with Peruvian nationality law passed in 1996, his birth was registered at a Peruvian embassy or consulate before he reached 18 years of age (Consulado General del Peru en Washington, D. C.). In addition, Peruvian law mandates the presence of the child at an embassy to complete this process. His parents did not complete these requirements - thus he did not acquire Peruvian citizenship.

Another population that has been affected and rendered stateless in Chile as a result of the interpretation of "in transit" are indigenous populations. One such group is the Aymaras, an indigenous group that lives along the border of Peru and Chile ("Born in the Americas": 61). According to the report, "Born in the Americas," the Aymaras are a nomadic population that travel from Chile and Peru year round as shepherds and crafters. Sometimes during the course of their travels, Aymaras women give birth to children in Chile. But as a result of their transitory lifestyle, these women are not deemed to permanently reside in Chile. In such instances where an Aymara woman gives birth to a child in Chile, the child is not recognized by the Chilean government as being a citizen of Chile ("Born in the Americas": 61). What is more, being impoverished and having to traveling far distances prevent many individuals from being able to travel to an embassy or consulate to register the child's birth - much less travel back to their country of origin to do so (Lawson and 
Rodriguez, 2017: 10). The Open Justice Society characterizes the problems as follows:

\begin{abstract}
Researchers have documented nearly 200 cases of Aymara children who were registered in Chile as born to "in transit" parents and were therefore denied Chilean nationality. Rectifying the situation for these children and ensuring others do not fall into the same gap has been complicated by language barriers -some Aymaras do not speak Spanish, and the authorities do not speaking Aymara- cultural barriers, and the absence of governmental entities in the area ("Born in the Americas": 61)
\end{abstract}

In spite of being born without the formal recognition of nationality and citizenship, Aymaras children are still able to go to school and receive an education. The caveat is that their years of schooling are not formally recognized - meaning that their official grade level in school may not be recognized and they are subject to being placed in a grade not commensurate with their level of development or intellectual capacity. This can cause an Aymaras (or any) child to feel out of place and stigmatized. In addition, the child may not receive an education coterminous to his or her developmental level. More formally, these children "cannot access the 'beca indígena'- a special scholarship the Chilean government provides to indigenous people to finance the cost of post-secondary education" ("Born in the Americas": 61).

\title{
5.1 The road to effectuating change in Chile
}

The problem of statelessness in Chile has been traced back to an interpretation of "in-transit" that began in 1995 (Lawson and Rodriguez, 2017: 5). Although the UNHCR created its initiative in 2014, Chile was not initially a part of the campaign. Joining the campaign required States to affirmatively hold themselves accountable for the problems that existed within their own jurisdictions. This required affected communities within such States to generate awareness of these issues and push for key governmental actors to adopt applicable international laws and practices. In 2015, a number of human rights advocacy groups concerned about the situation in Chile did just that. The Im- 
migration and Refugee Law Clinic at the Diego Portales University (Chile) ("UDP"), the Center for Human Rights and the Immigration Law Clinic at the Alberto Hurtado University School (Chile) ("UAH"), and the Jesuit Migrant Services ("JMS") all came together to form an initiative to coordinate advocacy, research and community outreach to promote the recognition of Chilean nationality (Lawson and Rodriguez, 2017: 5). This effort was quite arduous and required hours of extensive advocacy to first find the affected populations and then determine adequate solutions.

The UDP, UAH and JMS sought to bring legal action before the Chilean Supreme Court to prompt change in the interpretative application of the "intransit" clause in the Chilean constitution. The Chilean Supreme Court had historically held that the term "in-transit" must be interpreted "in its natural, obvious meaning" (Lawson and Rodriguez, 2017: 8). The UDP, UAH and JMS group sought to change this by bringing a suit before the Court in which the affected individuals would challenge the Chilean government's denial of their basic human right to a nationality. One major initial problem was finding members for their class action lawsuit. Volunteers had to comb through records of the Civil Registry of Chile to identify individuals registered as a "Child of Non-resident Foreigner" (Lawson and Rodriguez, 2017: 9). Another challenge that the UDP, UAH, and JMS collaborative faced was that many of the people that they did identify no longer lived at the address of record. Therefore, members of this collaborative often had to go door-to-door and work with local school administrators to locate affected individuals. In the end, the UDP, UAH, and JMS coalition were able to locate 167 individuals who had been affected (Lawson and Rodriguez, 2017: 9).

On November 10, 2015, the aforementioned collaborative filed a collective nationality claim with the Supreme Court of Chile. The Ministry of Foreign Affairs provided support to the nationality claim and cited to international human rights standards, prior Court decisions, and even international court decisions (Lawson and Rodriguez, 2017: 11). The most persuasive precedent was the Case of the Girls Yean and Bosico v. Dominican Republic - a case in which the Inter-American Court of Human Rights held that "nationality is an essential human right and an attribute of the human personality, and no one can be arbitrarily deprived of it" (Lawson and Rodriguez, 2017: 11). 
Ultimately, on November 24, 2015, the Supreme Court of Chile decided to grant all 167 claimants Chilean nationality. This resulted in a minor victory because even though it resolved the case of these particular 167 individuals, the Supreme Court declined to address whether this would extend to all similarly situated stateless individuals in Chile. This came to serve as proof that piecemeal litigation and favorable judicial decisions alone were not sufficient to more broadly rectify statelessness in Chile. Rather, pressure aimed at a wider array of governmental institutions was necessary. Following the minor victory made with the Supreme Court of Chile, the UDP, UAH and JMS coalition decided to move forward to create a more sustainable project. These organizations decided to collaborate with the Department on Migration of the Ministry of Interior and the Civil Registry to undertake a new initiative (Lawson and Rodriguez, 2017: 12). This effort sought to attack the problem of statelessness through a more robust approach. As Lawson and Rodriguez note, "this project included an in-depth analysis of the administrative procedure in place for the confirmation of nationality; the systematisation of all the information available on the CTF and the implementation of activities for the confirmation of the Chilean nationality of those children whose nationality had been denied at birth" (Lawson and Rodriguez, 2017: 12). These groups also worked in conjunction with the UNHCR and, as a result, a new initiative was born - \#Chilereconoce. Advocates of the \#Chilereconoce movement recognized that there were critical challenges that they faced in trying to address the problem of statelessness in Chile. They found that there were legal deficiencies, administrative deficiencies, policy shortcomings, and lack of access to justice - all of which had previously been identified by existing international plans of actions.

\subsection{Implementing policies and solutions}

\#Chilereconoce is a pilot project that was launched as a sub-movement of the UNHCR's \#IBelong project - which seeks to eradicate statelessness globally by the year 2024. The \#Chilereconoce initiative was instituted in 2016 as a plan to address and correct the problem of statelessness that affected thou- 
sands of children in Chile ("Presidenta Bachelet encabeza lanzamiento del proyecto "Chile Reconoce"”, 2017). \#Chilereconoce is the first ever Chilean initiative on a national and regional level to promote the right to a nationality to all persons born in Chile. This project programmatically relies on the participation of governmental actors across different institutional levels of authority as well as the involvement of community actors. While the initiative is still in its relatively incipient stages, one positive indicator that the campaign is sustainable is that although there was a change in executive leadership in the country shortly after the initiative's inauguration (from Michelle Bachelet to Sebastián Pinera), the campaign continued to be implemented by the succeeding administration. As part of the \#Chilereconoce campaign, Chile implemented policies that were created by the UNHCR's \#IBelong Campaign and the Brazil Declaration and Plan of Action. Both of these campaigns' core principles share common tenets in their plans of action.

In December 2014, 28 countries and three Latin American and Caribbean territories met in Brazil and entered into the Brazil Declaration and Plan of Action (Mondelli, 2017: 45). Member states agreed that "no new cases of statelessness must originate in the region, all stateless persons must acquire or regain their nationality, and people at risk of statelessness need to be enabled to surmount any legal or practical barriers to prove that they are nationals of a specific country ... they also agreed that until stateless persons are able to obtain a nationality, they must be protected" (Mondelli, 2017: 45). The overarching purpose of the Brazil Declaration and Plan of Action is to reaffirm the applicability and validity of principles and standards of the 1951 Convention relating to the Status of Refugees and its 1967 Protocol for the protection of refugees in acceding states ("Brazil Declaration", 2014). This declaration stresses the importance of insuring that every human is given a nationality as it is their right and failure to do so should be regulated as a direct violation of international law. Chapter Six, Section (c) of the Brazil Declaration specifically advocates for a universal birth registration and issuance of proper documentation. It suggests that this may be achieved through, "1) the adoption of simplified administrative procedures; 2) the periodic organization of awareness campaigns and community outreach activities; or 3) the application of appropriate measures to ensure that rural or remote areas are reached, for 
example through mobile registration units. Section (h) of the Brazil Declaration further provides that facilitating the restoration or recovery of nationality should be achieved through legislation and inclusive policies.

Under the Brazil Declaration, there are three main strategies that are identified as being imperative to implement in order to address and eradicate statelessness. These three tactics are: prevention, protection, and resolution. According to Mondelli, prevention requires States to reconcile their individual State domestic nationality regulations with those of international standards and to facilitate an effective birth registration system that could be accessible to all members of their States (Mondelli, 2017: 2). Protection requires that all States which are parties to this plan accede to the 1954 Convention Relating to the Status of Stateless Persons, to take the extra steps in adopting domestic protection frameworks, and establish procedures to recognize the stateless populations in their States in order to offer protections (Mondelli, 2017: 2). As for resolutions, the Brazil Declaration calls for States to implement a solution that suites the specific needs of their own States. This step, according to Mondelli, necessitates that States craft projects that could review and verify birth certificates to ensure that they have been properly registered.

Chile took several important steps towards implementing these aforementioned strategies. One important first step Chile took was to change the interpretation of the term "in-transit" to mean only children of tourists and crew members. This was a significant move in preventing the creation of new cases of statelessness in Chile. This also allowed Chile to be in compliance with international laws under the 1954 Convention and the 1961 Convention because it meant that Chile was taking substantial steps to ensure that all individuals were granted a nationality and it further served to prevent the spread of statelessness. Chile also took a monumental step by acceding to both the 1954 Convention Relating to the Status of Stateless Persons and the 1961 Convention on the Reduction of Statelessness in April of 2018 ("UNHCR lauds Chile as it accedes to both UN Conventions on Statelessness," 2018). This was an important and necessary decision to make because it moved Chile towards achieving the goal of protection; protection could better be achieved via incorporating international law and its associated rights and protections into Chilean domestic law. Lastly, Chile took resolute action in this endeavor 
by getting key institutional actors (among them including the Department of Migration and Civil Registry) on board with the agenda of eradicating statelessness as well as implementing policy in a fashion that supports and advances this goal. While some of the impetus for the change in direction taken by Chile was driven by internal governmental motivations (including the leadership of president Bachelet), much of the credit must be given to advocacy groups who drew attention to the issue of statelessness in Chile, initiated litigation on behalf of affected persons, and undertook the arduous fieldwork required to bring the effort to full fruition.

\section{$\S 6$. Conclusion}

The investigation finds that the early assessments of the efficacy of Chile's statelessness reduction campaign are largely positive. This comes, however, with the full acknowledgement that the campaign only got into full swing in late 2016/early 2017. In addition, although there is a sizable extant literature on migration and human rights issues, there is a dearth of literature on the Chilean reform topic due to the program being in its relative incipient stages. Nevertheless, the feedback illustrates that the Chilean model can serve as a blueprint for other States to follow in their own efforts to reduce statelessness. Most impressively, some of the accolades that have been offered have come from parties who historically have been highly critical of Chile's failure to meaningfully address stateless and its reticence to accede to core international conventions on statelessness. For example, Lawson and Rodriguez have opined that "the results of \#Chilereconoce went above everybody's expectations" and that "\#Chilereconoce showed how different institutions (State, NGOs, academia, and International Organisations) can join efforts and strengthen each other's work, and in the end, produce a greater impact, in this case, to secure the right to a nationality and to contribute to the reduction of statelessness at a global level" (Lawson and Rodriguez, 2017: 13). As discussed above, Lawson and Rodriguez were part of a coalition of actors who were initially adversaries to those institutional actors within the government of Chile who had historically eschewed a more narrowly tailored 
interpretation of Chilean law that would have allowed for a more expansive inclusion of children born to migrant and indigenous persons into Chilean citizenship. Through the litigation strategies of this coalition, 100 children "were recognized as Chilean nationals, and administrative changes were brought about so as to ensure the right to a nationality to all people born in the country" (Lawson and Rodriguez, 2017: Abstract). In similar fashion, the UNHCR has identified Chile as a "model" and has offered positive words regarding the success of the \#Chilereconoce plan - opining the following:

The \#Chilereconoce project is a model of good practices at the international level, which confirms the Chilean State's commitment to the prevention and eradication of statelessness, as proposed by the global campaign \#IBelong of UNHCR, which seeks to end statelessness before of the year 2024. With these actions, Chile can position itself as a leader in this area in the region ("Presidenta Bachelet encabeza lanzamiento del proyecto 'Chile Reconoce"”, 2017).

The UNHCR found that within two years of the launch of \#Chilereconoce, 258 children had their Chilean nationality confirmed as a result of the campaign.

One of the major lessons learned from the Chilean experiment in tackling statelessness is that addressing statelessness is a difficult and challenging endeavor that cannot simply be entrusted to the proclivities of governmental actors - even if they may otherwise articulate a stance that they are willing to promulgate innovate measures to reduce statelessness. Constitutional principles and statutory constructs, as well as policy approaches fashioned by bureaucrats, create foundational and structural rules that form a basis for applying each to human lives and experiences for the purposes of reaching legal outcomes and decisions. These matters quite often become routinized and ladened with indifference to human impact. That is why litigation often becomes necessary; successful litigation can lead to a new articulation of how the law must be applied. As evidenced here, litigation was a vital tool towards helping achieve the inclusion of hundreds of affected persons into Chilean citizenship. The Chilean plan demonstrates that having a cadre of lawyers 
trained in the law of the forum country as well as international human rights law is a must. Such actors have experience working in the field and bring to bear on the process the necessary tools (e.g., knowledge of human rights law, an understanding of national laws, rules of procedure, the geographic lay of the land, social milieus, etc.) to advocate on behalf of affected persons. Lawyers as advocates have to be prepared to engage in grassroots activism by going into the field, traversing geographical distances (sometimes going into remote places), securing the services of interpreters who are able to communicate with affected persons - some who speak indigenous languages, as well as engaging in other critical tasks. Advocates must have a willingness and patience to plunder through voluminous records and documents. There will be times that much needed and required documents cannot be produced. This will require advocates to think outside the box; to come up with acceptable alternative forms of evidence.

Beyond the numbers of cases litigated with successful outcomes, what makes the Chilean plan a model for reducing statelessness? The answer can be found in the broader, holistic, strategy. The \#Chilereconoce project demonstrates that reducing stateless requires community action at the grassroots level, implementation of domestic legislation reform at the national level, and governmental accession to international treaties on reducing statelessness. There will be instances where obstacles - including legal deficiencies, administrative deficiencies, policy shortcomings, and lack of access to justice - must be confronted head on despite seemingly being insurmountable obstacles. Admittedly, the ability to tackle each of these challenging domains will be conditioned upon the structure and culture of government in which reformoriented actors must navigate. Perhaps the Chilean model works because Chile is a functioning democracy led by governmental actors who espouse and promote the extension of human rights. But Chile is a relatively young democracy (as of the 1990s), not a historical democratic juggernaut. Chile experienced many years of human rights violations under the reign of Augusto Pinochet - particularly in the 1970s. Thus, the case of Chile demonstrates that a State can even be somewhere just beyond the incipient stages of egalitarian governmental rule and effectuate meaningful reform in this domain. 


\section{BIBLIOGRAPHIC REFERENCES}

1946 Statute of the International Court of Justice

1948 Universal Declaration of Human Rights

1954 Convention Relating to the Status of Stateless Persons

1961 Convention on Reduction of Statelessness

1986 Vienna Convention on the Law of Treaties between States and International Organizations or Between International Organizations

1990 Convention on the Rights of the Child

2010 Constitucion Politica De La Republica De Chile

2014 Global Plan to End Statelessness

Arnold, R. What is Statelessness? United Nations High Commissioner for Refugee, accessed 01/03/2020. Available at: <https://www.unhcr.org/ ibelong/wp-content/uploads/UNHCR-Statelessness-2pager-ENG.pdf $>$.

Blitz, Brad K., Lynch, Maureen (2012). Statelessness and Citizenship: A Comparative Study on the Benefits of Nationality. Elgar, Edwards Publishing, Inc.

Consulado General de Peru en Washington, D.C., accessed 2/03/2020. Available at: <http://www.consulado.pe/es/Washington/tramite/Paginas/Births. aspx $>$.

Crook, John R. (2004). The International Court of Justice and Human Rights. Nw. J. Int'l. Hum. Rts (1).

Departamento de Extranjería y Migración. Requisitos Para Optar a la Nacionalidad Chilena, accessed 30/08/2020. Available at: <https://www. extranjeria.gob.cl/nacionalizacion/opcion-a-la-nacionalidad/>.

European Commission, Migration and Home Affairs (2011). Irregular Migration. Derived by EMN from IOM Glossary on Migration, 2nd. ed., accessed 25/04/2019. Available at: <https://ec.europa.eu/home-affairs/ content/irregular-migration-0_en>.

Giancarlo Alexis Figueroa Meza, Sentencia No. 9422-2013, Chile: Corte Suprema, 6 January 2014, accessed 6/05/2019. Available at: $<$ https://www. refworld.org/cases,CHIL_SC,530713474.html>. 
International Legal Research Tutorial, accessed 29/04/2020. Duke University. Available at: $<$ https://www.law.duke.edu/ilrt/cust_law_2.htm>.

La Nacionalidad de los Hijos de Extranjeros Nacidos en el País: Regulación en Chile y Sudamérica (2014). Biblioteca del Congreso Nacional de Chile, accessed 30/08/2020. Available at: <https://cutt.ly/vg0nfak>.

Lawson, Delfina, Rodriguez, Macarena. Addressing the Risk of Statelessness in Chile: From Strategic Litigation to \#Chilereconoce, accessed 01/03/2020. Available at: <https://namati.org/resources/addressing-therisk-of-statelessness-in-chile-from-strategic-litigation-to-chilereconoce>.

Middleton IV, Richard T., Wigginton, Sheridan (2012). A Comparative Analysis of How the Framing of the Jus Soli Doctrine Affects Immigrant Inclusion into a National Identity. Temple Political and Civil Rights Law Review 21(2), 521-542.

Mondelli, Juan Ignacio (2017). Eradicating Statelessness in the Americas, accessed 29/08/2020. Available at: <https://www.fmreview.org/sites/fmr/ files/FMRdownloads/en/latinamerica-caribbean/mondelli.pdf $>$.

Open Society Justice Institute (2017). Born in the Americas: The Promise and Practice of Nationality Laws in Brazil, Chile, and Colombia, accessed 30/08/2020. Available at: <https://www.justiceinitiative.org/ uploads/8c4136e4-c25d-4255-9afd-d66d20e71da1/born-in-the-americas -20170323.pdf>.

Presidenta Bachelet encabeza lanzamiento del proyecto "Chile Reconoce" para rectificar nacionalidad chilena de hijos de extranjeros transeúntes. (2017). Accessed 02/03/2020. Available at: <https://cutt.ly/Bg0nxSm>.

UNHCR (2012). Self-Study Module on Statelessness, accesed 29/04/2019. Available at: $<$ https://www.refworld.org/docid/50b899602.html $>$.

UNHCR (2017). "This Is Our Home”: Stateless Minorities and Their Search for Citizenship, accessed 01/03/2020. Available at: <https://www.unhcr. org/59f747404.pdf>.

UNHCR lauds Chile as it accedes to both UN Conventions on Statelessness (2018). Accessed 02/03/2020. Available at: <https://www.unhcr.org/en -us/news/briefing/2018/4/5ad5c2454/unhcr-lauds-chile-accedes-both-un -conventions-statelessness.html>. 
UNHCR. Brazil Declaration and Plan of Action, accessed 01/03/2020. Available at: $<$ https://acnur.org/cartegena30/en/brazil-declaration-and-plan-ofaction $/>$. 